\title{
ANTROPOLOGIA ANDINA, "ANDINISMO" Y SENDERO LUMINOSO
}

\section{Orin Starn}

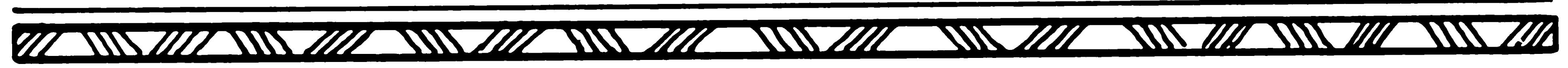

EL 17 DE MAYO DE 1980, militantes de Sendero Luminoso quemaron las ánforas en la comunidad andina de Chuschi y proclamaron su intención de derrocar al estado peruano. Lo que los senderistas luego llamarían el "ILA" -el inicio de la lucha armada- coincidió con el 1990 aniversario de la ejecución de Túpac Amaru II por los colonizadores españoles. Según versiones del mito de Inkarí, el cadáver del rebelde neo-Inca estaría destinado a recomponerse en una resurreción de la sociedad andina después del cataclismo de la conquista. Pero Chuschi prefiguró no un renacimiento, sino una década de muerte. Inauguró una guerra salvaje entre los insurgentes y el gobierno que costaría más de 20,000 vidas durante los años ochenta ${ }^{1}$.

Para cientos de antropólogos de la floreciente subespecialidad de estudios andinos, el surgimiento de Sendero

1 Entre los mejores trabajos en castellano sobre Sendero están los de Degregori (1986, 1990), Gorriti (1990), y Manrique (1989); en inglés, véase McClintock (1984), Palmer (1986) y Berg (1988). 


\section{ORIN STARN}

Luminoso fue una total sorpresa. Docenas de etnógrafos trabajaron en la sierra sur-andina durante los años 70 . R.T. Zuidema, uno de los más destacados especialistas en los Andes, dirigió un proyecto de investigación en la región de Río Pampas, que después se convertiría en un centro de la rebelión. Pero ningún antropólogo se percató de la insurrección que estaba a punto de estallar, una rebelión tan fiera que en 1990 el gobiemo central había declarado "zona de emergencia" y puesto bajo mando militar a nueve de los veinticuatro departamentos del país. La dificultad de los antropólogos para anticipar la insurgencia plantea cuestiones importantes. Después de todo, durante la mayor parte del presente siglo, los etnógrafos habíamos figurado como los expertos preeminentes sobre la vida en los Andes. Nos considerábamos como los forasteros "buenos" que realmente entendian los intereses y aspiraciones de la gente andina; $y$ hablamos con la autoridad científica sellada por la experiencia de primera mano del trabajo de campo. ¿Por qué entonces no se pudo anticipar la inminente tormenta de Sendero Luminoso? ¿Qué significa esto en relación al modo en que los etnográfos entienden la sierra? ¿Cómo los hechos de los últimos diez años nos obligan a repensar la antropología andina?

En primer lugar, quiero enfatizar que sería injusto culpar a los antropólogos por no predecir la rebelión. Definitivamente, no es tarea de los etnógrafos el prever revoluciones. De otro lado, los logros de Sendero hubieran sido especialmente difíciles de anticipar en muchos sentidos. Ni siquiera sus rivales en la izquierda ayacuchana de los años 70, como el Movimiento de Izquierda Revolucionaria (MIR) y Vanguardia Revolucionaria (VR), daban mucha importancia a esta agrupación pro-Revolución Cultural liderada por el profesor de filosofía Abimael Guzmán. Habiendo los maoístas perdido el control de la Universidad Nacional de San Cristóbal de Huamanga (UNSCH) a fines de los 70, ¿cómo creer que iban a protagonizar una 
Antropologia andina, "ANdinismo" y Sendero Luminoso

revolución armada? Durante los primeros meses de su insurreción, tampoco se hizo mucho caso a Sendero. ¿Qué grupo político anunciaría su presencia en Lima ahorcando un perro frente a la Embajada de China con el letrero "Deng Tsiao- Ping, hijo de perra"? La mayoría de los comentaristas simplemente descartaban a Sendero, calificándolo como una secta extravagante pero no tan peligrosa, marxismo doctrinario en la década de la perestroika.

Lo que sí aseveraré es que la mayoría de los antropólogos no tenían ojos en ese momento para ver, en la realidad, las condiciones que hacian posible el surgimiento de Sendero. En primer lugar, muchos tendian a ignorar las cada vez más intensas interconexiones entre el campo y la ciudad, las comunidades rurales y los pueblos jóvenes, y entre la sierra andina y las tierras bajas de la selva y la costa. De estos enlaces surgirian la enorme reserva de jóvenes radicales de identidad rural/urbana amalgamada de la cual la dirigencia senderista reclutaria una efectiva fuerza revolucionaria. En segundo lugar, los antropólogos mayormente hicieron caso omiso al ambiente de agudo descontento a lo largo de las empobrecidas serranías andinas. Cientos de protestas $e$ invasiones atestiguaron un arraigado resentimiento que los militantes de Sendero explotarian con parcial éxito.

Para comenzar a explicar los vacios en el conocimiento etnográfico de la sierra, la primera parte de este ensayo introduce el concepto de "Andinismo"2. Me refiero aquí a representaciones que sitúan fuera de la historia moderna a los actuales campesinos serranos. Durante el siglo XX, se han extendido a lo largo de las fronteras

2 En el original en inglés, "Andeanism". Tanto "Andeanism" como "Andeanist" presentan un problema de traducción, dado que sus homólogos en castellano, "Andinismo" y "andinista", suenan a alpinismo, cosa que no sucede con "Andeanism" y "Andeanist" en inglés. Por falta de otra alternativa, sin embargo, los editores han utilizado los términos "Andinismo" y "andinista". 


\section{ORIN STARN}

discursivas imágenes de la vida andina como si ésta hubiera permanecido intocada desde la época de la conquista española, para convertirse en un motivo central en los escritos de novelistas, políticos y viajeros, además de las representaciones visuales de cineastas, pintores y fotógrafos. Creo que el Andinismo circulaba también en antropología, y que su presencia nos ayuda a explicar porque tantos etnógrafos no se percataron de las crecientes interconexiones que fueron un factor vital en el desarollo de Sendero Luminoso.

Por supuesto, el Andinismo no fue la única influencia sobre los antropólogos de los años 60 y 70 . La creciente importancia de modelos ecológicos y simbólicos en la teoría antropológica internacional de la época también condicionaba la comprensión etnográfica de los Andes, especialmente de los estudiosos de Europa y Norteamérica. En la segunda parte del ensayo, intento mostrar que el fuerte impacto de estas dos corrientes teóricas produjeron una intensa preocupación sobre cuestiones de adaptación ecológica, ritual y cosmológica. Este enfoque limitado, a la vez, ayuda a entender por qué tantos antropólogos pasaron por alto el profundo descontento rural con el status quo, que se convertiria en un segundo factor que permitió el crecimiento de Sendero.

Mi análisis de la antropología andinista arranca con To Defend Ourselves: Ecology and Ritual in an Andean Village (Para defendernos a nosotros mismos: ecología y ritual en una aldea andina) de la antropóloga norteamericana Billie Jean Isbell (1977). A través de una lectura cuidadosa de esta ampliamente leida etnografía -una de las más influyentes en los estudios andinos norteamericanosempiezo a delinear la huella del Andinismo sobre el pensamiento antropológico y a explorar cómo la abrumadora recurrencia a modelos ecológicos y símbólicos condujo hacia la omisión del fermento político en el campo. Este libro tiene un significado especial porque la aldea andina sobre la que se trabajó fue Chuschi, donde la insurreción 
Antropologla andina, "Andinismo" y Sendero Luminoso

de Sendero estallaría a sólo cinco años de la salida de Isbell.

Yuxtapongo To Defend Ourselves con el extraordinario pero poco conocido Ayacucho: Hambre y Esperanza, escrito por el agrónomo chotano Antonio Díaz Martínez ${ }^{3}$, entonces profesor en la UNSCH y futuro líder de Sendero Luminoso. Hambre y Esperanza nos muestra la posibilidad de formular una interpretación de la sierra muy distinta a la de la antropología andinista. Mientras Isbell y otros etnógrafos nos mostraron aldeas aisladas con tradiciones eternas, Díaz observó un sincretismo e identidades cambiantes. Gran parte de los antropólogos vieron al campesinado como esencialmente conservador. Díaz, por el contrario, pensaba que muchos pequeños agricultores estaban al borde de la insurrección. Partes de Hambre y Esperanza anticipan lo que sería el dogmatismo brutal de Sendero. Pero el hombre que luego se convertiría en el número tres de la insurgencia maoísta, después de Guzmán y Osmán Morote, descubrió un Ayacucho que escapaba de la voluminosa literatura antropológica, un campo a punto de estallar en guerra.

A través de una reflexión crítica sobre la antropología andinista de los años 60 y 70 , mi análisis se encamina hacia las alternativas. Enfatizo la necesidad de reconocer lo que el historiador Steve Stern (1987:9) llama "la multitud de maneras por las cuales los campesinos se han involucrado continuamente en sus mundos políticos" y abogo por un entendimiento de las identidades andinas modernas como entidades dinámicas, sincréticas $y$, a veces, ambiguas. Finalmente, busco desarrollar un análisis que no subestime la importancia del terror en el accionar de Sendero pero que reconozca los íntimos enlaces de muchos de sus militantes con el campo, así como la existencia de corrientes de simpatía por su insurrección.

3 Harding (1988) ha escrito un ensayo que hasta donde yo sé- es el único estudio sobre Díaz. 
Siento cierta incomodidad al escribir sobre los Andes y Sendero Luminoso. La senderología ya es una pequeña empresa. Demasiado a menudo -y especialmente en los trabajos de los especialistas norteamericanos en el tema- desaparece en estos estudios el sentido del intenso sufrimiento humano causado por la guerra. El terror se vuelve simplemente un nuevo campo para el debate académico. Este trabajo está abierto a la crítica de estar contribuyendo a la comercialización académica de la guerra. Pero ofrezco el ensayo en un espíritu de compromiso, en la esperanza de que una nueva comprensión de la situación pueda contribuir a entender la violencia y a construir caminos hacia la paz.

Isbell escribió To Defend Ourselves a partir de su trabajo de campo realizado en los años 1967, 1969-70, y 1974-75. Lleno de ricos y agudamente observados detalles, el libro presenta a la comunidad de Chuschi dividida en dos segmentos: campesinos quechua-hablantes, por un lado, y profesores y burócratas hispano-hablantes por el otro. En la periferia del libro aparece una categoría intermedia: los migrantes de Chuschi a Lima. Como otros andinistas, Isbell se ubica firmemente al lado de los comuneros. Los mestizos, aún los empobrecidos profesores, son para Isbell los malos de la película, personajes antipáticos $y$ sin conocimiento o aprecio por las tradiciones andinas. El análisis de Isbell se centra en el planteamiento de que los campesinos de Chuschi se habían ensimismado para mantener sus tradiciones contra las presiones externas. Los comuneros, aseveraba, construyeron un orden símbolico y social con una lógica binaria que enfatizaba su diferencia de los "vecinos", los mestizos de Chuschi. Combinando el entonces influyente estructuralismo de Claude Lévi-Strauss con el concepto de Eric Wolf 
Antropologla ANdina, "ANDinismo" y Sendero Luminoso

de la "comunidad corporativa cerrada", Isbell (1977:11) se asignó la tarea de documentar las "defensas estructurales que la población indigena ha construido contra la creciente dominación del mundo exterior."

Isbell señalo que Chuschi era una capital de distrito con una feria importante, una iglesia, un colegio $y$ un puesto sanitario. Notó el tránsito de camiones que conectaba a Chuschi con la ciudad de Huamanga. Nos enteramos del movimiento constante de personas y mercaderia, no sólo entre Chuschi y Huamanga sino también entre Lima y la selva. Más de una cuarta parte de la población de Chuschi había migrado a Lima. Muchos otros dejaban la comunidad por temporadas. Incluso la mayoría de los migrantes "permanentes" mantenían estrechos lazos con su aldea natal, regresando de vez en cuando y manteniendo animales $y$ tierras.

Sin embargo, al representar la cultura chuschina, Isbell minimizaba el sincretismo y el cambio. Al contrario, se concentraba en las maneras en que el ritual, el parentesco, la reciprocidad, la cosmología y el manejo ecológico de los comuneros, encarnaban "la estabilidad de las costumbres tradicionales" (Isbell 1977:3). Trazaba paralelos entre el ciclo ritual anual de los Incas según Guamán Poma y el de los chuschinos modernos. Una larga sección presenta las costumbres de bodas como no alteradas desde la época incaica. Las fotografias que acompañaban el texto reiteran el sentido de una sociedad no tocada por el tiempo. Dos campesinos aran con una yunta de toros. Un grupo de hombres toma aguardiente en una minka. Una mujer ofrece chicha a la Pacha Mama. En To Defend Ourselves, la identidad cultural aparece como una cuestión de preservación. A pesar del cambio, subrayaba Isbell, los comuneros habian conservado sus tradiciones distintivamente andinas, "manteniendo el orden fundamental de su sociedad y cosmologia" (Isbell 1977:105).

Hay que situar el énfasis de Isbell en la continuidad y la "otredad" no-occidental de Chuschi en relación 


\section{ORIN StaRn}

a la tradición de representación que quiero denominar como el Andinismo. En el resumen de James Clifford (1988:258) del concepto de Orientalismo del crítico palestino-americano Edward Said, se tiende "a dicotomizar (en el Orientalismo) el continuum humano en contrastes nosotros-ellos y a esencializar el 'otro' resultante, para hablar del 'modo de pensar oriental', por ejemplo, o hasta para generalizar sobre 'Islam' o 'los árabes'". El Andinismo tiene una lógica similar. Dicotomiza entre el occidental y no-occidental, costeño y serrano, urbano y rural, mestizo e indígena; luego esencializa el lado serrano de la ecuación para hablar de "lo andino", "la cosmología andina", "la cultura andina" $o$, en términos más anticuados, "el modo de pensar andino" o "los indígenas andinos". Se retrata "la tradición andina" como eterna, una herencia del pasado pre-colombino. Palabras como "indígena", "autóctono" $e$ "indio" son aplicadas al moderno campesino serrano.

El Andinismo representa una cara de lo que Johannes Fabian (1983:147) denomina "el proceso ideológico por la cual las relaciones entre el Occidente y su Otro ... son concebidas no sólo como diferencia sino como distancia en el espacio y el tiempo". Sin embargo, como otros discursos sobre el Tercer Mundo, el Andinismo también tiene su historia propia. Sus raices más inmediatas datan de los principios del siglo XX. En un contexto histórico internacional de retroceso de la teoría social evolucionista que dominaba las ciencias sociales del siglo XIX, surge el movimiento político $e$ intelectual del indigenismo, con un vigoroso ataque a anteriores percepciones sobre los campesinos andinos como seres inferiores, y un nuevo enfoque en el que los agricultores serranos eran, en realidad, los portadores de una noble herencia precolonial ${ }^{4}$.

4 Véase Salomon (1985) para una buena discusión del indigenismo y el problema de la representación de los andes en las primeras décadas de este siglo. 


\section{Antropologla ANdina, "ANDinismo" y Sendero Luminoso}

Como escribió Luis Valcárcel (1938:7), uno de los principales intelectuales indigenistas peruanos, gracias al indigenismo "ya no hay nadie que dude que el indio de ahora es el mismo indio quien, hace un milenio, creo dinámicas y variadas civilizaciones en la vasta área cultural de los Andes".

Cuestiones de identidad nacional influian en el trabajo de indigenistas peruanos como Valcárcel y Manuel González Prada. Un entendimiento de los campesinos como los guardianes del pasado incaico, coincidia con los deseos de muchos intelectuales y políticos de ver una alternativa potencial a la desacreditada herencia de los españoles y la cultura capitalista de los países del norte. Socialistas como Castro Pozo y Mariátegui esperaban que el "socialismo incaico" -que suponían se encarnaba en la cultura andina contemporánea- podía ser la base de un orden postcolonial más justo.

A partir de los años 30, el concepto de una tradición andina intacta se había difundido para hacerse sentir en el arte, la política y la ciencia. Las novelas conmovedoras de Ciro Alegria y José María Arguedas celebraban las tradiciones "puras" del agricultor andino. Peliculas documentales como El hechizar de Alejandro Mamani (1974) y En las huellas de Taytacha (1985) dieron expresión visual al Andinismo con sus imágenes de un campesinado ritualista, en comunión con la naturaleza y aferrado a sus tradiciones. La agencia de viajes Wilderness Travel Company en Berkeley, California, se basa en el Andinismo para hacer propaganda de sus excursiones en un lenguaje que apela a la búsqueda del viajero occidental de lo autóctono $e$ incontaminado por la modernidad:

En nuestra más reciente expedicion en los Andes ... nos encontramos con indios quechuas espléndidamente vestidos, manadas de llamas y alpacas decoradas con cintas de alegres colores, pastoreando en idílicos prados andinos ... los habitantes 


\section{ORIN StaRn}

locales no hablan el castellano ... y mantienen una relación mística con la tierra ${ }^{5}$.

Un guía de excursiones nos asegura que:

"Te sientes como si hubieras caído en el túnel del tiempo cuando te sientas en la plaza adormecida de una aldea $y$ te das cuenta ... que ha permanecido virtualmente sin cambios desde tiempos incaicos".

Este es el Andinismo puro. Se extrae totalmente la experiencia andina de la historia, en este caso para atraer al visitante potencial norteamericano. A lo largo de las diez páginas del texto, no se hace mención en ningún momento a la guerra entre Sendero y las fuerzas oficiales.

El lenguaje de Wilderness Travel señala una ironía clave. Por un lado, el andinismo tiene un sentido igualitario y antiracista. Varios autores, desde Castro Pozo a Isbell, buscan mostramos la riqueza de la cultura andina y la explotación de los campesinos serranos bajo el orden colonial y postcolonial. Por el otro, persisten en el discurso andinista residuos de paternalismo y jerarquía. Personas urbanas de clase media y alta conservan el privilegio de representar y hablar por los agricultores pobres, y el evolucionismo recrudece en las constantes descripciones de los campesinos contemporáneos como los portadores de creencias "premodemas". Luis Valcárcel creía en la igualdad racial. Pero en 1950 todavía podía invocar al pensamiento evolucionista para proclamar que dentro de las "accidentadas fronteras del Perú, personas de antecedentes

5 Las citas vienen del catálogo de 1990 de Wilderness Travel, pp.63-68. El catálogo de otra compañía norteamericana de trekking, Mountain Travel, usa términos muy semejantes. 
occidentales conviven con otros que pertenecen a épocas largamente sumergidas en la marea de la historia" (1950:1).

Sería un error sobreestimar la coherencia o influencia del Andinismo. En Orientalismo, Said se dedica a demostrar la dependencia de representanciones del Medio Oriente de imágenes de la distancia, el exoticismo y la eternidad. Las innovadoras pero demasiado nítidas polémicas de la obra, no examinan las variaciones y tensiones a lo largo y al interior de los parcialmente autónomos discursos orientalistas de la literatura de viajeros, novelistas, historiadores, etnógrafos y periodistas. Como muchos criticos han observado, Said hace la misma operación esencialista que critica en los orientalistas. Todas las representaciones occidentales del Medio Oriente, desde Homero a Flaubert, son barridas en la misma categoria monolítica de Orientalismo.

Los antropólogos andinistas de los años 60 y 70 frecuentemente iban en contra de las presuposiciones del Andinismo ${ }^{6}$. Cabe recordar que a fines de los años 60 comenzaron las críticas contra los modelos sincrónicos de análisis social en la antropología norteamericana $y$, con ello, nuevos intentos de vincular la etnografía con la historia. Desde el inicio de los 70, varios antropólogos llevaron el ataque contra el ahistoricismo a los estudios andinos. Por ejemplo, el inteligente trabajo de Frank Salomon (1973:465) sobre Otavalo, habló contra "el estereotipo de sociedades indigenas como herméticamente cerradas, estáticas e históricamente condenadas a desaparecer". Desde una perspectiva marxista se desarrolló en los paises andinos la "antropología de lucha", con la cual estudiosos perspicaces como Rodrigo Montoya (1980) y Silvia Rivera Cusicanqui (1984) examinaron las transformaciones que la expansión capitalista había supuesto para la vida de los

6 Un buen ejemplo de una etnografía norteamericana que rompió completamente con el andinismo es The Bolivian Aymara de Hans y Judith-Maria Buechler (1971). 
campesinos serranos. Al promediar los años 70, la mayor parte de la antropología sobre la sierra había difundido un sentido de la importancia de una perspectiva histórica.

Pero el Andinismo también sobrevivió en la etnografía andinista. Imágenes de una eterna tradición andina continuaban apareciendo en los escritos antropológicos acerca de todos los aspectos de la vida serrana. R. T. Zuidema y U. Quispe (1973:362, 377) utilizaron el sueño de una anciana campesina para mostrar que la estructura social serrana moderna era "todavía similar a la de las comunidades indigenas del Siglo XVI ... esencialmente igual a la incaica". Giorgio Alberti y Enrique Mayer (1974:21) describieron el sistema económico andino de la misma manera: "A pesar del decurso de cuatro siglos, muchas de las formas de reciprocidad simétrica existentes en tiempo de los incas y aún antes ... continuán funcionando en el presente." Sobre la religión, J. V. Núñez del Prado (1974:25) concluyó: "Encontramos que el mundo sobrenatural tiene características muy similares a las que tenía durante el imperio incaico". Hermann Trimborn (1969:145) confirmó: "Muchas de las observancias particulares y domésticas de la antigua religión sobrevivieron y todavía se practican hoy".

También persistía la yuxtaposición del occidental y el andino. El Andinismo tendía a formular el contraste en términos del presunto individualismo y alienación de occidente contra los ideales comunales y la estrecha relación con la naturaleza en la cultura andina. Muchos antropólogos seguian el mismo esquema. Como Joseph Bastien (1978:xxv), que concluyó así el prefacio a Mountain of the Condor (La montaña del condor): "Lo que hemos poseido, también lo hemos destruido. Los andinos, en contraste, están en armonía con su tierra". Paul Doughty (1968:1) mezcló su formulación del contraste andino/ occidental con una aseveración de la eternidad andina: "Los indios han sobrevivido en una reserva provincial, escasamente afectados por las vicisitudes del tiempo, la 


\section{Antropologia ANDina, "ANDinismo" y Sendero Luminoso}

política, la sociedad y las innovaciones tecnológicas que tanto han conmovido a la civilización occidental".

Hay que enfatizar que el Andinismo no sólo infiltraba las etnografías principalmente escritas y leídas por especialistas en los Andes. También aparecía en trabajos sobre los Andes concebidos para un público académico más amplio. Especialmente notable fue el caso del influyente The Devil and Commodity Fetishism in South America (El diablo y el fetichismo de las comodidades en Sudamérica) de Michael Taussig, ahora uno de los más influyentes y conocidos antropólogos en los EE.UU. Este original y apasionado libro atrajo gran atención en todas las ciencias sociales en los EE.UU. Pero estaba también cargado de Andinismo. En clásico estilo andinista, Taussig insistió en pintar la cultura serrana como una herencia directa de la época pre-colonial. De esta manera podía hacer caso omiso a casi quinientos años de constantes cambios para aseverar que "las instituciones pre-colombinas todavía florecen en los Andes" y que los campesinos contemporáneos viven en "comunidades precapitalistas" y poseen creencias "paganas" (Taussig 1980:159- 160). Taussig $(1980: 27,161)$ también adoptó la yuxtaposición convencional de las tradiciones occidentales y andinas para contrastar la "atomización y servidumbre" del capitalismo occidental con la creencia en "la unidad total que existe entre las personas, los espíritus y la tierra" en la "metafísica andina". En los términos de Taussig, los quince millones de diversos habitantes de una sierra de 5,000 km2. se vuelven "indios andinos" puros para los fines de una tremendamente simplificada dicotomía nosotros/ellos. Para ser justos, el nuevo libro de Taussig (1987) sobre el terror $y$ el curanderismo en el Putumayo colombiano se aparta de una visión romántica y esencializada de la "cultura andina" expresada en The Devil y va hacia una visión de los Andes como un lugar de identidades multiples, cambiantes y sincréticas, formuladas todas dentro del contexto común de la expansión colonial y neocolonial. Pero el 


\section{ORIN STARN}

análisis de The Devil, por parte de un etnógrafo que como Taussig siempre se ha considerado un retador de las normas, nos muestra claramente la presencia del Andinismo en la imaginación antropológica.

Las visiones etnográficas de la "otredad" perenne de lo andino tenían una lógica auto-realizadora. En su afán de estudiar la cultura andina "indigena", los antropólogos buscaron las regiones más ostensiblemente tradicionales para sus investigaciones. La mayoría preferia -como consta en la franca explicación de Harold Skar (1982:23) sobre su elección de Mataquio en Apurímac- los lugares "donde la cultura tradicional quechua pareciera más intacta". En el Perú, los etnógrafos se dirigían hacia la zona sur-andina, donde los campesinos hablaban quechua o aymara, tenían ayllus y sistemas de cargos $y$ vivian en el corazón histórico del imperio incaico. Casi por completo, hicieron caso omiso de la sierra norte con su campesinado hispano-hablante y más "aculturado". Esta virtual separación de la sierra norte de la literatura etnográfica ayudaba a mantener una imagen del campo andino como territorio de ayllus $e$ idiomas autóctonos, un lugar con pocos cambios respecto del pasado antiguo.

Llegando a sus lugares escogidos, la mayoría de los etnógrafos volvian a resaltar los aspectos aparentemente más tradicionales de la vida serrana. Pequeños agricultores que podian ser ubicados en el rol de "indio andino" (en inglés, "Andean Indian") captaban la mayor parte del espacio en las etnografías. Profesores, sanitarios, agrónomos, burócratas y sacerdotes fueron relegados a papeles marginales. Así fue que Isbell dedicó casi todo To Defend Ourselves a los comuneros de Chuschi. Los muchos mestizos de la aldea aparecen sólo en los breves pasajes que los marcan como los pesados opresores de los campesinos. Es seguro que la mayoría de los mestizos chuschinos hablaban quechua, idioma común no sólo entre los campesinos sino también entre las clases medias en Ayacucho. Algunos eran chuschinos de tercera generación. 


\section{Antropologia andina, "ANdinismo" y Sendero Luminoso}

Pero el uso de Isbell del término "los nativos" -como en una sección subtitulada "El concepto de los nativos sobre su ecología"- comprendía sólo a los comuneros. Desde la perspectiva de Isbell, los campesinos eran los únicos verdaderos andinos en Chuschi.

También se reflejaba la fuerte presencia del Andinismo en la antropología de los años 60 y 70 en el uso insistente por los etnógrafos del contraste entre "indios" $y$ "mestizos." Con "cholo" como una categoría intermedia, este sistema de clasificción colocaba a antropólogos como Isbell en la tradición de mirar a los campesinos serranos a través de lentes que acentuaban sus raices pre-colombinas. Los pequeños agricultores fueron registrados en la categoría de "indio". Como se sabe, esta es una palabra poco usada por los campesinos peruanos para describirse, llevando consigo hasta un sentido de inferioridad y desprecio. La mayor parte de los agricultores de la sierra se identificaban ya en los años 60 y 70 -dependiendo del contexto- como "campesinos" o "agricultores", o a través de su región, comunidad o familia. Pero el término "indio" que siempre ha significado "otredad" en el pensamiento occidental- era perfecto para antropólogos que querian pintar a los pobladores de los Andes como fundamentalmente no-occidentales. Michael Olien (1973:245) podía escribir que un "indio andino...es una persona que lleva ojotas, vive en una choza con paredes de adobe $y$ techo de paja, mantiene 'creencias paganas' $y$ habla qechua o aymara". Cholos y mestizos aparecian, especialmente en las etnografías escritas por norteamericanos, como progresivamente más ocidentalizados, muestras abyectas de la corrupción de la auténtica cultura andina.

Era precisamente como consecuencia de su énfasis sobre el isomorfismo de las tradiciones andinas que los antropólogos tendian a hacer caso omiso a las características fluidas y muchas veces ambiguas de la identidad personal en los Andes. La tipología de indio, cholo y mestizo 


\section{ORIN STARN}

sugeria tres esferas autónomas de personalidad. Esto contradijo la experiencia mucho menos clara de cientos de miles de serranos. Durante el siglo XX, por lo menos un cuarto de millón de agricultores andinos migraron hacia la selva y más de un millón fueron a Lima. Migraciones temporales llevaron a miles más por frecuentes viajes entre la sierra, la Amazonia, y la costa. Esta masiva movilidad significaba que muchos pobladores de las comunidades más apartadas habían vivido en la costa. A la vez, muchos habitantes de las enormes barriadas de Lima, La Paz, Quito, y Bogotá mantenían fuertes vínculos con el campo. La distancia entre chozas serranas de barro $y$ paja $y$ viviendas urbanas de calamina, cartón y estera, no era la existente entre una sociedad andina "indigena" y la modernidad "occidentalizada". Al contrario: era el espacio entre diferentes puntos en un circuito estrechamente integrado por el parentesco y las lealtades comunales y la constante circulación de mercadería, ideas y personas. Indio, cholo, mestizo no eran categorías discretas, sino posiciones parcialmente coincidentes en un continuum.

El surgimiento de Sendero Luminoso subrayaba las continuidades entre las diferentes ubicaciones en el circuito campo/ciudad. El movimiento fue fundado $y$ dirigido por intelectuales urbanos liderados por Guzmán. Pero jóvenes colegiales y universitarios, muchos de ellos de origen campesino, eran la base de la insurrección. Muchos tenían amigos y parientes en sus comunidades natales. Pero la mayoría también había estudiado en la ciudad, volviéndose radicales al ser expuestos a un discurso revolucionario que respondía a su propia experiencia de la pobreza y la falta de oportunidades. Estos jóvenes se convirtieron en los activistas que comenzaron a trabajar en el campo desde fines de los años 70 y que luego tomarian las armas en los años 80.

La habilidad de los jóvenes senderistas para iniciar una insurrección masiva, expresaba las interpenetraciones entre las diferentes posiciones en el círculo rural/urbano. 
Un mayor grado de educación y el rígido lenguaje del marxismo separaba a los senderistas de los campesinos. Pero la mayoría de los insurgentes también era gente pobre con rasgos serranos, comprensión del quechua y un entendimiento de la geografía física y texturas culturales de la sierra. Como explica el historiador Jaime Urrutia:

"Sendero avanza porque son ellos quienes (en las sierra) se asemejan al pueblo. Ellos no son de clase media, no son distintos físicamente, hablan el mismo lenguaje y la gente los siente próximos a ellos"7.

Por supuesto, sería peligroso olvidarnos de cómo la llegada de Sendero a una comunidad puede ser un acto repentino y lleno de violencia $y$ terror. Pero Urrutia también nos ayuda a cuestionar la metáfora favorita del discurso contrainsurgente del Estado peruano, empleada en Vietnam, El Salvador y en todo lugar donde los gobiernos combaten la insurgencia guerrillera: que los senderistas son nada más que "terroristas" o "subversivos", una fuerza completamente externa al campesinado. Precisamente lo que distingue a Sendero de los movimientos guerrilleros peruanos de los 60 -aparte de la crueldad de los maoístasson las estrechas conexiones de muchos senderistas con la sierra. Los universitarios $e$ intelectuales mayormente limeños del ELN de Luis de la Puente Uceda fueron rápidamente barridos por el Ejército. En cambio, muchos de los jóvenes de Sendero conocen los tortuosos caminos de la sierra, saben cómo sobrevivir a las noches heladas, cómo evitar a las patrullas de las fuerzas armadas, cómo entremezclarse con la población civil y reagruparse cuando las fuerzas de seguridad se retiran. En fin, los insurgentes tienen muchas veces una suerte de doble status en las

7 La entrevista está en Quehacer, no. 57, pp. 42-56. 


\section{ORIN STARN}

comunidades serranas. Pueden a la vez ser "insiders" y "outsiders".

Francisco Lombardi nos proporciona una visión de esta amibiguedad en una escena de La Boca del Lobo, filme basado en la masacre de Soccos en 1983. La película cuenta la ocupación por el ejército de la aldea ficticia de Chuspi -un juego de palabras con el verdadero Chuschi. Luego del subrepticio izamiento de la hoz y el martillo sobre el puesto policial, los soldados comienzan una búsqueda casa por casa. Dos jovenes reclutas derriban la puerta de una casa de piso de tierra, descubren un pequeño taller de retablos $y$, debajo de un retablo, un plano del puesto policial. Los dos soldados cogen al joven artesano -vestido de poncho y ojotas- cuando éste intenta escapar. Lo golpean y con orgullo lo entregan a su comandante. Pero el retablista no confiesa pertenecer a Sendero, aún bajo quemaduras de un cigarillo. Perturbado por la tortura y hasta dudoso de que el preso hable el castellano, el comandante se decide a llevarlo en camión al cuartel. Pero los senderistas emboscan la camioneta, matan a los soldados y liberan el preso, desencadenando una serie de acontencimientos que terminan con la masacre de más de treinta campesinos por el ejército.

Esta secuencia no sólo llama la atencion sobre la brutalidad de la guerra, sino también sobre la identidad mixta de Sendero. Para el espectador, igual que para los soldados, nunca está realmente claro si el retablista era o no senderista. La evidencia del plano y luego la emboscada indican involucramiento. Pero el aparente monolinguismo quechua del preso -junto con su traje campesino y su profesión de artesano- chocan con la imagen popular de los militantes de Sendero como propagandistas universitarios. Resulta dificíl establecer la línea divisoria entre los comuneros indígenas y los revolucionarios cholos. Los soldados peruanos, como la tropa norteamericana en Vietnam, enfentan a un enemigo que no se distingue fácilmente de la población rural. En lugar de hacer el 
paciente trabajo de distinguir a los senderistas, el ejército emprende un terror indiscriminado.

Era precisamente el sentido de identidades ambiguas desarrollado por Lomabardi en su ficticia Chuspi lo que hacía falta en el retrato del verdadero Chuschi por Isbell. Los antropólogos andinistas documentaron y analizaron cuidadosamente las costumbres de las comunidades serranas. Pero tendían a barnizar las coincidencias $e$ interrelaciones que se convertirian en importantes elementos en el surgimiento de Sendero Luminoso.

Nacido en Chota-Cajamarca, Antonio Díaz Martínez se tituló en la Univesidad Nacional Agraria de La Molina en $1957^{\circ}$. Tres años de trabajo para el estado dieron al joven ingeniero la oportunidad de supervisar una colonización planificada en la ceja de selva y de viajar a Suiza, España, Egipto y Chile. Pero Díaz volvió desilusionado por el trabajo estatal. Al promediar los años 60 , se integró a la facultad de agronomía en la UNSCH donde Abimael Guzmán estaba consolidando la facción maoista que luego sería Sendero Luminoso. Fue desde el clima radical en la universidad que Díaz escribió Ayacucho, Hambre y Esperanza. Lo hizo con una mezcla coloquial de descripción, diálogo y anécdota en base a sus viajes por Ayacucho entre 1965 y 1969. Pero Hambre y Esperanza también promulgaba un mensaje claro. La "obsoleta estructura colonial" de Ayacucho tendría que ser derrocada (Díaz 1969:33). La región sólo podría progresar a través del "cambio económico social" y la recuperación de "lo valioso en el arte, música, costumbres y valores de nuestro pueblo" (1969:265). (1988:66-67).

8 Esta información biográfica sobre Díaz viene de Harding 
Hambre y Esperanza refracta al Andinismo. Como muchos antropólogos, Díaz creía en la sobrevivencia de una tradición andina indígena que se podía yuxtaponer con la cultura de la conquista occidental. El también trazaba la división entre campesinos tradicionales y mestizos corruptos. Desde el punto de vista de Díaz, la minka y los ayllus eran la prueba de que los ayacuchanos del campo habían heredado una ética comunal de los incas. De manera semejante a los socialistas peruanos de las primeras décadas del siglo $\mathrm{XX}$, Díaz pensaba que esta tradición de cooperación podría convertirse en la base de un nuevo orden social.

El sabor andinista compartido por Hambre y Esperanza y muchas etnografías señala las importantes intersecciones que siempre han existido entre la politica socialista y la investigación antropológica sobre los Andes. La etnología y el pensamiento socialista -al igual que el periodismo, la arqueología y la ficción- estaban estrechamente ligados en el indigenismo de las primeras décadas del siglo XX. En el pequeño mundo de los peruanos y extranjeros que escribian sobre los Andes durante los años 20 y 30, Mariátegui y Castro Pozo podian citar a Valcárcel y Julio C. Tello y, a la vez, ser citados por los antropólogos nortemericanos Wendell Bennet y Bernard Mishkin. Las investigaciones académicas se hicieron progresivamente más especializadas con el dramático aumento en el número de los estudiosos extranjeros andinistas después de la segunda guerra mundial, causada en gran parte por el rápido crecimiento de los sistemas universitarios en Europa y Norteamérica. Pero las intersecciones también discurrian por las varias ramas del discurso urbano sobre los Andes. Un ejemplo fue la trayectoria de $\mathrm{Ar}$ guedas. El escribió poesía y novelas sobre la sierra, trabajaba como un curador de artefactos arqueológicos andinos y publicaba investigaciones etnográficas. El pueblo de Puquio sirvió a Arguedas como escenario tanto de su trabajo etnográfico como de la gran novela Yawar Fiesta. 


\section{Antropologia andina, "Andinismo" y Sendero Luminoso}

Si bien la antropología y la política socialista ya no estaban tan entremezcladas como en la época de Mariátegui, los etnógrafos andinistas de los años 60 y 70 se convertían en primos intelectuales de los políticos que hablaban de un retomo a las tradiciones andinas de la minka y el ayllu.

Sin embargo, a diferencia de muchos otros socialistas y antropólogos, Díaz hizo una ruptura parcial con el Andinismo. El agrónomo chotano reconocía las agudas diferencias culturales y económicas que separaban a un campesino serrano de un funcionario costeño. Pero nunca perdió el sentido de la movilidad y el sincretismo. En cada rincón de Ayacucho, Díaz encontraba a personas que no cabian en las simples categorías de indio, cholo o mestizo. Nos presenta a mestizos pobres que hablan quechua, comuneros que viajan constantemente a Lima, niños en Apurímac que son trilingües: quechua, castellano y campa. Las instantáneas de estas diferentes personas en Hambre y Esperanza desestabilizan las tipologías simples y cuestionan las fáciles separaciones entre la sociedad andina "tradicional" y la cultura mestiza "moderna". Díaz describió a José de la Cruz como :

un hombre de 45 años, mestizo, habla muy bien el español, emigró de la región siendo muy niño, logró cuatro años de estudios primarios...cuando niño trabajó en Lima cuidando el perro y el jardín de un "gringo", de joven viajó al valle selvático de Chanchamayo en la selva, donde trabajó como peón. Años duros, nos dice... Inquieto, transhumante, viajo posteriormente al Ucayali, durante algunos años trabajó en Contamaná... El es bilingüe, su esposa es monolingüe castellano, los niños están aprendiendo el "runa simi"... hace ocho años retornó a su tierra natal...(donde] obtuvo en herencia un pedazo de suelo (1969:142). 


\section{ORIN STARN}

El nómade de la Cruz hablaba quechua y vivía por el momento como campesino, contradiciendo la simplificada presentación de los mestizos como privilegidos hispanohablantes en To Defend Ourselves. En una desolada comunidad en Cangallo, Díaz (1969:144) encontró a Anastasio Alarcón, un campesino que:

no bebe porque es protestante. Tiene cinco hijos pequeños que quedan con la madre cuando él viaja a Lima entre los meses de mayo a octubre. Va a la capital a trabajar como obrero de construcción civil, ganando cien soles diarios....Tiene tres hectáreas de terreno, una la siembra con papas, otra con trigo, maíz y cebada y la restante, que descansa, la dedica como pasto para sus tres vacunos; tres cerdos y algunas gallinas completan el patrimonio.

Aquí un comunero que habla quechua $y$ que debería entrar en la categoria de "indio" resultaba pasar parte de su tiempo en Lima y ser miembro de una iglesia evangélica. De nuevo nuestra certidumbre sobre la autencidad, sobre quién cabe dónde, vuelve a ser cuestionada. En vez de poder distinguir automáticamente entre indios, cholos y mestizos, descubrimos una población interconectada, movilizándose en diversas posiciones en un circuito muy transitado entre la ciudad y el campo, costa, sierra y selva, la comunidad campesina y el pueblo joven.

Se puede explicar una parte del entendimiento de Díaz por su amplio punto de vista, mayor que el de los etnógrafos con su enfoque limitado sobre una comunidad específica. El visitó comunidades aparentamente tradicionales como Quispillacta y Pomacocha, pero también pasó mucho tiempo en las haciendas feudales de La Mar, las colonizaciones en la selva de Apurimac, las barriadas de Ayacucho, las polvorientas estaciones de camiones de 
Huanta. Estos eran lugares donde la profundidad de la movilidad $e$ interconexión andina eran imposibles de ignorar.

No siendo científico social, Díaz también escribió sin necesidad de fijar a personas en categorías analíticas demasiado rígidas. Al igual que otros antropólogos de los años 60 y 70, los andinistas recurrían casi exclusivamente a lo que Francoise Michel-Jones (1978:14) denomina "sujetos absolutos" (Los Nuer, los Hopi, los Dogon). En To Defend Ourselves, por ejemplo, no encontramos a los chuschinos como individuos. En su lugar, Isbell (1977:73) hablaba de cómo "los comuneros participan en la economía [nacional] de una manera limitada" o cómo "los vecinos usan la exogamía aldeana para asegurar su movilidad social' ${ }^{9}$, como si los pobladores y los mestizos pudieran ser considerados categorías homogéneas, cuyos miembros comparten creencias idénticas. En cambio, Díaz presentaba siempre caracteres únicos. Algunos de sus personajes, como el hacendado autoritario de Orcasitas, operan simplemente como emblemas de tipos sociales. Pero Díaz describía a otros, como Alarcón y Cruz, con un sentido de variación e individualidad. Él también se refería a "los mestizos" y "los comuneros." Pero las voces plurales y los largos diálogos entre Díaz y diferentes ayacuchanos nos dan la comprensión de los matices y de la parcial inestabilidad de la identidad individual, rasgo que mayormente faltaba en la antropología andinista con su confianza en la claridad de las fronteras sociales andinas.

Finalmente, la perspectiva marxista de Díaz le ayudaba a establecer los vínculos internos del Perú moderno.

9 Isbell si hace una distinción entre tres niveles económicos dentro de la categoria de comunero: apukuna, wachakuna y tiypakuq. Pero insiste en que la división entre comuneros y vecinos es la más fundamental en Chuschi, y la mayor parte del libro habla de estos dos grupos como entidades homogéneas. 


\section{ORIN STARN}

De la mano con su entendimiento muchas veces romántico de la "pureza" de la cultura andina, los marxistas desde los años 30 también habian desplegado el concepto de clase para delinear la posición común en el fondo de la píramide económica peruana de los comuneros serranos $y$ de los empobrecidos pobladores urbanos. Fue así que mientras Díaz mantenía su imagen idealizada de lo andino, también reconocía que la experiencia de la pobreza conectaba a personas de identidades diferentes por todo Ayacucho. Este nexo económico era uno que muchos antropólogos -mayormente dependientes de los conceptos de "cultura" y "comunidad"- estaban poco preparados para examinar. El interés en la economía política que comenzaba a surgir en la antropología norteamericana en los años 70 -que hubiera llevado a los etnógrafos a explorar más profundamente cuestiones de clase- llegó tarde para los estudiosos norteamericanos andinistas ${ }^{10}$.

El retrato en Hambre y Esperanza de la comunidad de Moya, treinta kilómetros al sur de Ayacucho, tipificaba el reconocimiento de Díaz (1969:53) de las profundas interpenetraciones de la vida andina. Comienza con una descripción que enfatiza la preservación de las tradiciones y una autonomia pastoral en Moya.

No hay hacienda en ese anexo, todos son pequeños campesinos-propietarios con minúsculas "chacras" que van de $1 / 6$ a $1 / 2$ hect. por familia. En conjunto se denominan ellos mismo miembros de la comunidad. Estas parcelas, de propiedad privada $e$ individual, son trabajadas también individualmente, aunque a veces se practica el "ayni" $y$ la "minka"... Las casas del pueblo se hallan dis-

10 Una mayor cantidad de trabajos sobre los Andes por antropólogos desde una perspectiva de política económica comenzarian a aparecer en los años 80 (Collins 1989, Orlove, Foley y Love 1989, Roseberry 1983). 
tribuídas en toda la suave ladera; el color rojo de los tejados y las paredes de adobe se combinan con el verde oscuro de los alisos, dando el paisaje una belleza muy singular.

Pero Díaz no se contentó con presentar a Moya como una comunidad estable y autosuficiente. Entró en conversaciones con un grupo de hombres que hacian trabajo comunal para construir una escuela. En vez de analizar el evento como una expresión de la perenne colectividad andina, describió a los comuneros fumando cigarillos "National" y empleando madera y cemento obtenido de Cooperación Popular. Descubrimos a la población de Moya en constante movimiento. Sin tierras suficientes, muchos habían ido a la costa o la selva. Otros migraban entre la comunidad y las haciendas azucareras costeñas donde trabajaban de peones. Aunque aprecia el éxito de la comunidad en mantener algunos elementos de colectividad y estabilidad, Díaz (1969:56) termina presentando imágenes de la actual fluidez y el incierto futuro de Moya:

Seguimos caminando, conversamos con algunos campesinos viejos que están en sus casas. Sólo los hombres viejos se quedan permanentemente en la comunidad, los jóvenes han emigrado, a veces vuelven para ayudar en las siembras y cosechas $y$ luego desaparecen para volver a aparecer en la fiesta comunal o en las próximas cosechas.

Aquí estaba el sentido de las interconexiones que posibilitaría el crecimiento de Sendero Luminoso. Aquí también estaban los jóvenes con el conocimiento tanto de la ciudad como del campo, de los cuales Guzmán, Morote y Díaz mismo comenzarian a reclutar una guerrilla. Trece años después Moya formaría parte de una zona de dominio de Sendero. 


\section{Orin StaRn}

Si los múltiples lazos entre la ciudad y el campo facilitaron el crecimiento de Sendero en Ayacucho desde la UNSCH, el éxito inmediato de los senderistas en ganar apoyo en el campo testimoniaba el fuerte descontento de muchos campesinos con el statu quo. Por supuesto, es vital enfatizar que la violencia y el terror también han sido una arma básica de los seguidores de Guzmán. Desde la matanza de 60 campesinos en Lucanamarca en 1983 hasta el "ajusticiamiento" de cientos de tenientes gobemadores y jefes de comités de defensa civil, la violencia ha sido un instrumento primordial de Sendero. Como proclama el mismo Guzmán, "La violencia es una ley universal; una clase no puede ser reemplazada por otra, ni el viejo orden ser superado para crear uno nuevo sin la violencia revolucionaria "11.

Sin embargo, no se puede negar que al mismo tiempo han habido claras evidencias de corrientes de apoyo a Sendero a través de los diez años de guerra. En el caso de Ayacucho, esto ha sido más notable entre 1980 y 1982, lo que Carlos Iván Degregori llama la época de "autoritarismo utópico" de Sendero, antes de la feroz contraofensiva de las fuerzas armadas. El periodista Raúl González (1982:47) al preguntar sobre Sendero a mediados de 1982, recibió respuestas casi unánimes: "Es un movimiento apoyado por los campesinos jóvenes. Los viejos están resignados a su suerte, pero apoyan a sus hijos". A inicios de 1983, dirigentes campesinos en Huancayo dijeron a la investigadora norteamericana Cynthia McClintock (1984:54) que "la mayoría sustancial [de los campesinos] apoyaban [a Senderol." David Scott Palmer (1986:129) concluyó que hasta 1985 Sendero mantenía

$"$ La cita viene de la llamada "entrevista del siglo" en El Diario, 31 de julio 1988 , p.15. 
Antropologla ANDina, "ANdinismo" y Sendero Luminoso

una "sustancial reserva de apoyo" en el campo de Ayacucho. Desde 1985, los senderistas habían desarrollado también un nuevo y lucrativo bastión en el Alto Huallaga como defensores de los campesinos cocaleros, en su mayoría migrantes serranos, contra los narcotraficantes colombianos y el gobiemo. En parte fue por estas corrientes de apoyo popular -siempre a la mano con su uso del terror y el miedo- que Sendero creció tan rápidamente en los años 80. En diciembre de 1982, el gobiemo central declaró en estado de emergencia y bajo control de las fuerzas armadas a nueve de las 181 provincias del país. Este número había crecido a 56 al promediar 1989.

Aunque siempre han habido variaciones importantes dependiendo de la zona y el momento, los senderistas utilizaron una estrategia similar en muchas comunidades de Ayacucho, Huancavelica, Andahuaylas y Junín. Llegaron predicando la lucha armada; en zonas de cooperativas, frecuentamente redistribuyendo la tierra y el ganado. El llamado a un cambio radical tuvo una cierta atracción para muchos comuneros. Los jóvenes guerilleros, que a veces contaban con parientes en las comunidades que iban a organizar, conocían el quechua y la vida serrana, lo que con frecuencia les daba la capacidad de comunicar su mensaje revolucionario con eficiencia. Las ejecuciones de autoridades locales corruptas $y$ de abigeos eran muchas veces recibidas con aprobación. La a menudo violenta llegada de las fuerzas policiales o armadas podía espantar el apoyo a Sendero. Pero las tácticas del terror también podian ser contraproducentes, creando un resentimiento que redundaba en beneficio de los insurgentes.

En los años 60 y 70 habían muchas señales de descontento entre el campesinado, que Sendero aprovecharía en los 80 . La creciente presión campesina fue un elemento que llevó a Velasco a decidirse por la reforma agraria. Los años 60 trajeron numerosas invasiones, huelgas $y$ el fortalecimiento de federaciones campesinas regionales y nacionales. Sólo en 1963, el politólogo Howard 


\section{ORIN STARN}

Handelman (1975:121) estimó que los campesinos protagonizaron entre 350 y 400 invasiones en el sur andino peruano. Miles de campesinos continuaban movilizándose durante esa década, aunque normalmente la policía actuaba del lado de los poderes locales y muchos campesinos murieron bajo el fuego de las fuerzas de seguridad. La reforma agraria no detuvo el descontento. Algunos fundos no fueron divididos. Las nuevas SAIS y CAP resultaron ineficientes. El estado no apoyó al campesinado con préstamos o asistencia técnica, aún cuando la rétorica oficial de igualdad y orgullo campesino durante los primeros años de Velasco ayudaron a politizar aún más a muchos campesinos. En partes de Ayacucho y Apurímac, la protesta campesina se intensificó. Ahora muchos campesinos no sólo invadían haciendas no parceladas sino también las cooperativas. Las ligas agrarias formadas originalmente bajo Velasco se volvieron más independientes $y$, a fines de los 70 , se extendía por la sierra un mosaico de federaciones campesinas militantes, a menudo vinculadas a partidos de la izquierda ${ }^{12}$.

Sin embargo, la antropología andinista hizo poco caso a estas importantes corrientes de descontento entre el campesinado y su frecuente recurso a la acción colectiva. To Defend Ourselves reflejaba la tendencia a ignorar la actividad política rural. Isbell mostraba a los chuschinos descontentos de sus relaciones con los mestizos. Pero enfatizaba el conservadurismo de los comuneros, su deseo de mantener la continuidad de sus tradiciones andinas. Su argumento se basaba en símiles de defensa. Los campesinos "defienden su forma de vivir", "mantienen el encierro social", "se encierran socialmente y económicamente para fortalecer sus defensas contra las intrusiones del mundo exterior" (Isbell: 197, 243). Sólo se atribuía

12 El reciente estudio de la comunidad de Huasicancha en el Valle del Mantaro de Gavin Smith (1989) da una mirada de cerca a la historia de protesta en una comunidad andina en la sierra sur-central. 
ANtropologla andina, "ANDinismo" y Sendero Luminoso

deseos de cambio a los maestros mestizos y a los que migraban a Lima. En un pasaje que ignoraba que los campesinos también querian el cambio, Isbell (1977:237) escribía: "Los campesinos han escogido la estrategia de proteger lo que tienen, mientras los maestros radicales han escogido estrategias para ganar lo que no tienen: mejores sueldos, movilidad social, y el poder de influir en las decisiones".

Isbell sólo nos presenta señales de iniciativa politica de los campesinos chuschinos en el postscriptum a su estadía en 1975. Alli nos cuenta que en febrero de 1972 los comuneros habian expulsado al sacerdote local, cansados del control que la iglesia ejercía sobre animales y tierras. En abril de 1975, los chuschinos organizaron una invasión masiva de una hacienda vecina que no fue dividida en la reforma agraria. Después de la ocupación, doscientos chuschinos hicieron el largo viaje a Ayacucho para reclamar reconocimiento legal para la tierra.

Todo esto sugería una voluntad de tomar acciones decididas y hasta arriesgadas. Pero Isbell se quedó con su retrato de los comuneros como políticamente conservadores. Presentaba a los migrantes como los lideres de ambos movimientos, como si los comuneros no protagonizaran acciones tan agresivas por sí mismos y como si gran parte de ellos no hubieran apoyado las dos iniciativas mencionadas. A pesar de su carácter ofensivo, Isbell (1977:243) presentaba finalmente ambos eventos como una mayor evidencia de "los comuneros ... intentando fortalecer sus mecanismos de aislamiento defensivo".

En justicia a Isbell, ella por lo menos notaba las evidencias de la movilización campesina. Muchos otro andinistas ignoraron completamente las muchas huelgas $e$ invasiones no sólo en los Andes peruanos, sino también en Bolivia, Colombia $y$, con menos intensidad, en Ecuador. El estudio de los movimientos campesinos fue dejado mayormente a los politólogos, periodistas y abogados. La unica etnografía norteamericana conocida que trataba cen- 


\section{ORIN STARN}

tralmente la protesta, la excelente We Eat the Mines and the Mines Eat Us (Nosotros comemos las minas y las minas nos comen) de June Nash (1978), no era sobre la movilización política en el campo, sino sobre el movimiento sindical de los mineros bolivianos. De las 464 publicaciones citadas por Frank Salomon (1982) en su extenso resumen de la etnología andina de los años 70, sólo cinco trataban directamente de movimientos campesinos. En sintesis, como disciplina la antropología casi eludió sistemáticamente uno de los asuntos más importantes de la época.

Parte de la explicación reside en el estado de la teoría antropológica de los años 60 y $70^{13}$. Hasta el surgimiento de la escuela de economía política al promediar los años 70, mucha de la discusión -especialmente en los EE.UU.- entraba en el campo general de la ecología cultural o de la antropología simbólica. Esta configuración se extendía a los estudios andinos. Aparecieron gran cantidad de trabajos en torno a la cuestión de la adaptación ecológica/cultural andina; otro gran número de estudios se vinculaban a la cosmología, el parentesco y el ritual. No se dio espacio para el análisis de la movilización y protesta política en ninguno de los dos lados.

La desaparición de cuestiones políticas era más aparente en el trabajo de los antropólogos ecológicos. Con el crecimiento explosivo de la escuela de ecología cultural en la antropología norteamericana a fines de los 60, antropólogos como Stephen Brush, Glynn Custred, Jorge Flores Ochoa, R. Brooke Thomas y Bruce Winterhalder convirtieron el estudio de los ecosistemas andinos en una especialidad popular. En sus a menudo perspicaces estudios, estos investigadores reconocieron que la vida serrana moderna reflejaba la experiencia de la conquista es-

13 El ya clásico artículo "Theory in Anthropology Since the Sixties" por Sherry Ortner (1984) es la mejor introducción al estado de la disciplina en los EE.UU. durante los 60 y 70. 


\section{Antropologia andina, "ANdinismo" y Sendero luminoso}

pañola y el contacto con el capitalismo. Algunos -el más notable de los cuales fue el norteamericano Benjamin Orlove- combinaban intereses en el medio ambiente con la economía política para forjar una etnografía creativa y sensible a la historia. Sin embargo, la mayor parte de la literatura seguía la línea de las estrellas de la antropología ecológica como Marvin Harris y Roy Rappaport. Así, muchos antropólogos enfatizaron el desarrollo por los campesinos andinos de adaptaciones estables a un ambiente de altura. Los estudiosos más inclinados a la biología documentaron los grandes pulmones de los agricultores serranos y su éxito en desarrollar especies de cereales y papa adecuados al frío y la altura. Otros, como Brush y Flores Ochoa, analizaron cómo el sistema andino de tenencia de la tierra y el manejo del ganado eran adaptados especialmente a la ecología de la zona. El carácter preciso de la "verticalidad ecológica" de los Andes -el término inventado por John Murra para describir cómo los estados pre-incaicos controlaban la tierra en diferentes alturas- se hizo un tema de interés especial. Subrayando la calidad auto-regulatoria y distintiva de la ecología andina, la literatura ecológica calzaba bién con la presuposición del Andinismo de una tradición andina discreta y estable. Los autores de colecciones como Man in the Andes (E] hombre en los Andes, Baker and Little 1976) y Pastores de puna (Flores Ochoa 1977) podian discutir con minuciosidad la adaptación cultural andina en lugares como Puno, Ayacucho y Huancayo, sin hacer mucho caso a la agitación política y a una revolución inminente.

Había un poco más de interés en la política rural en el lado cultural de la etnografía andinista. Bajo la influencia del estructuralismo de Lévi-Strauss y/o la antropología interpretiva de Clifford Geertz, antropólogos como Joseph Bastien, Leslie Brownrigg, Olivia Harris, Luis Millones, Tristan Platt y R. T. Zuidema publicaron muchos - y a menudo también perspicaces- nuevos trabajos sobre los clásicos temas andinistas del ritual, la reciprocidad, el 


\section{ORIN STARN}

parentesco y la cosmología. Mientras los antropólogos de orientación ecológica hicieron de la "ecología vertical" un área especial de investigación, la estructura del ayllu se convirtió en el enfoque de muchos de los estudiosos de orientación simbólica. Antropólogos como Taussig (1980) y Nathan Wachtel (1977) analizaron la cultura serrana en el contexto de la conquista y la llegada del capitalismo. Pero conservaron una visión de creencias andinas eternas que coincidían con los conceptos del Andinismo. Lo mismo que la literatura sobre la ecología cultural, el debate en tomo a la estructura de la cultura andina se convirtió en un proyecto tan absorbente que era posible hacer caso omiso a las condiciones de descontento rural que ayudarian a abrir paso a Sendero. Al promediar los años 70, los intentos de unir perspectivas ecológicas y símbolicas -en un espíritu de síntesis, Isbell dio el subtítulo de "ecología y ritual" a su libro- sólo perpetuaban la insensibilidad antropológica hacia la iniciativa política de los campesinos serranos.

Más allá de sus estrechos y parcialmente distorsionados lentes teóricos, otro factor en el descuido del descontento rural fue la orientación de los andinistas hacia sus sujetos etnográficos. En los años 50 , aún prevalecía la visión paternalista de la gente andina como rústicos atrasados $e$ ignorantes que tendrian que volverse agricultores modernos. El conocido antropólogo ecológico Julian Steward (1963:xxix) juntó la imagen andinista de los serranos como "indios" no-ocidentalizados con la retórica de la modernización típica de los 50:

Debido a que el poco entendimiento de los indios de los sistemas europeos les deja mal preparados para resolver sus propios problemas, se está realizando grandes esfuerzos para rehabilitarlos económicamente, a través de la restauración de tierras y métodos mejorados de agricultura, $y$ de reintegrarlos culturalmente, a través de la educación y otros 
Antropologla andina, "ANDinismo" y Sendero Luminoso

modos diseñados para facilitar su participación más amplia en la vida nacional.

La convicción según la cual los campesinos necesitaban una dosis de iniciativa occidental y tecnología moderna guiaba a los antropólogos de la Universidad de Cornell que, en los años 50, compraron la hacienda de Vicos en el Callejón de Huaylas para supervisar el proceso por el cual los ex-peones entrarian en el camino hacia la modernidad.

Este paternalismo desvergonzado había mayormente desaparecido al promediar los 60 con la creciente ola de críticas contra las presuposiciones de la teoria de la modernización. El sabor de la antropología andinista durante los 60 y 70 era crecientemente redentor. Algunos etnógrafos apuntaban problemas de rivalidades y conflictos dentro de las comunidades campesinas (Bolton 1973, 1974; Stein 1962). Pero la mayoría enfatizaba unilateralmente la durabilidad y el valor de las tradiciones andinas. Aunque a veces se acercaban a la presunción condescendiente de hablar por la gente serrana, es importante reconocer que los antropólogos hicieron llegar un mensaje importante a los funcionarios gubernamentales y administradores de agencias de desarrollo sobre la necesidad de respetar las prácticas y opiniones de los campesinos. Estudios antropológicos mostraron cómo los campesinos tenían un conocimiento sofisticado de su ambiente, complejos almanaques rituales y sistemas astronómicos, así como memorias vibrantes de su pasado. Una literatura importante surgió sobre los beneficios fisiológicos de masticar la coca, una costumbre considerada antes evidencia del atraso andino.

Sin embargo, el proyecto de la redención de lo andino jugó también un papel en el proceso por el cual muchos andinistas minimizaron el aspecto menos pintoresco de la vida serrana: la insistente pobreza que llevaba a tantos campesinos a acciones reivindicativas. Todo andinista reconocía la pobreza. Pero el énfasis de la adap- 


\section{ORIN STARN}

tación ecológica y el simbolismo sofisticado tenía como consecuencia una tendencia a subestimar la gravedad y extensión del sufrimiento económico en el campo. Los etnógrafos normalmente hacían poco más que mencionar las terribles tasas de mortalidad infantil, los minúsculos ingresos familiares, el corto promedio de vida, los elevados estados de desnutrición y la falta de servicios de salud, tan comunes en los Andes. Es cierto que la vida campesina siempre quedaba llena de momentos de alegría y placer. Pero los índices que llevarían a otros observadores a llamar a Ayacucho región de pobreza del "cuarto mundo" vendría como una sorpresa para alguien que conociera la zona sólo a partir de la etnografía de Isbell, Skar o Zuidema. Ellos nos dieron retratos detallados de intercambios ceremoniales, rituales de días de santos, bodas, bautismos y minqas. Otro tipo de escena, igualmente común en los Andes, casi jamás aparecía: la niña con disentería y sin atención médica, la mujer que se desangraba al dar a luz, una pareja campesina en su oscura casa de adobe llorando la muerte repentina de un infante.

En sintesis, la mayor parte de la antropología andinista no percibía el explosivo dolor y descontento en la sierra. Este resentimiento, por supuesto, no se traduciría sencillamente en apoyo para Sendero Luminoso. Durante los once años de la guerra, muchos campesinos, aún en las zonas de intensa actividad senderista en Ayacucho, Huancavelica y Junín, han rechazado las propuestas de los guerrilleros, pagándolo muchas veces con sus vidas. Aún en las comunidades donde Sendero ha logrado mucho apoyo, siempre hay quienes se han resistido al control de los maoístas.

Pero también han existido claras evidencias de corrientes de aceptación en determinadas zonas, indicando que Sendero ha trabajado en el campo no sólo en base a la coerción sino también a la persuasión. Entre 198082 , Chuschi se convirtió en sólo una de las muchas comunidades donde Sendero recibiría una bienvenida calu- 


\section{Antropologla ANdina, "ANdinismo" y Sendero LUminoso}

rosa. La gran mayoría de chuschinos vieron favorablemente la ejecución de dos abigeos por Sendero, el castigo a látigo de dos más y la expulsión de cinco funcionarios supuestamente corruptos. En agosto de 1982, muchos chuschinos estuvieron entre los 2,000 campesinos de nueve comunidades que se juntaron en una invasión a la granja agrícola de la UNSCH dirigida por Sendero. En diciembre, las comunidades se reunieron en Chuschi en una entusiasta marcha para celebrar la formación del "Ejército Guerrillero Popular". Diez cuadras de campesinos ondearon banderas rojas y dieron vivas a la "guerra revolucionaria".

En la breve sección final de To Defend Ourselves sobre el futuro de Chuschi, Isbell (1977:244-245) escribió que "el consumismo y los nuevos valores culturales debidos al incremento de la migración y la educación, pueden en algún momento causar cambios en la perspectiva de la comunidad". Pero su aseveración principal era que el cambio aún no había sucedido y que los comuneros en el futuro cercano "mantendrían sus actitudes conservadoras" y continuarian "los esfuerzos para resistir la incorporación en la economía y cultura nacionales". El impacto de los mestizos radicales sería "mínimo porque, como se ha explicado anteriormente, ellos no comparten las preocupaciones políticas de los comuneros, quienes están intentando proteger su aislamiento cultural".

Como tantos otros andinistas, Isbell había subestimado drásticamente los deseos de cambio de los ayacuchanos pobres. Lejos de rechazar la ideología radical y de "intentar proteger su aislamiento cultural", muchos chuschinos $y$ otros campesinos andinos estaban listos para acoger el concepto de la revolución, por lo menos hasta que entendieran la profundidad del autoritarismo senderista $y$ el costo que las FF.AA. les haría pagar por apoyar la insurgencia. El precio que los chuschinos pagarían por haber apoyado inicialmente a Sendero resultaría terriblemente alto. Durante 1983 y 1984, con la entrada del ejército a Ayacucho, las fuerzas gubernamentales desapa- 
ORIN STARN

recieron a seis campesinos de Chuschi y a 46 de la vecina comunidad de Quispillacta. Una patrulla de Sinchis despedazó a un chuschino anciano con una granada de guerra en la placita de la comunidad. En 1985, el ejército había incendiado una parte de la aldea. Muchos comuneros huyeron hacia los pueblos jóvenes de Ayacucho y Lima $^{14}$.

Como sugiere el título de su libro, Antonio Díaz Martínez hizo de las ásperas condiciones sociales existentes en la región un enfoque especial en Ayacucho, Hambre y Esperanza. El análisis de Díaz anticipaba la línea oficial de Sendero Luminoso. El joven agrónomo consideraba que la pobreza de la sierra era no sólo resultado de su incorporación en la economía mundial, sino del estancamiento de la región en un sistema semi-feudal dominado por terratenientes y parásitos burocráticos. Pero el Díaz de 1969 escribía con una sutileza que desaparecería por completo en las rígidas fórmulas maoístas de Sendero. El resultado fue un retrato intimo y sensible de las muchas dimensiones de la pobreza ayacuchana: agricultores ricos comprando terrenos de pequeños parceleros en Cangallo, hacendados en Apurimac pagando una miseria a sus peones, campesinos con parcelas demasiado pequeñas para subsistir, comunidades en conflicto con las haciendas $y$ entre ellas.

Antropólogos como R. Brooke Thomas (1976:403) enfatizaron que los campesinos hicieron "una adaptación

14 Esta información proviene de la nota introductoria de Isbell a la segunda edición de To Defend Ourselves. No es un error muy importante, pero en esta introducción Isbell se equivoca en relación a la fecha de inicio de la lucha armada en Chuschi, poniéndola como el 18 de mayo en vez de la fecha real, el 17. 
exitosa a una de las regiones más duras habitadas por el hombre." En cambio, Díaz (1969:65-66) percibia tierras que eran "erosionadas, escasamente irrigadas, extremadamente divididas... cansadas y deforestadas". Lejos de adaptarse a su ambiente montañoso, los campesinos eran forzados a trasladarse hacia el circuito ocupado por la selva, las montañas y a la costa:

La Costa, las minas de Cerro de Pasco, la Selva de Apurimac les sirven como escape a la pobreza del terruño, ofreciéndoles fuentes de trabajo temporal o permanente $y$ algunos ingresos económicos. Después de las siembras van a estos centros de trabajo de los que regresan para las cosechas, trayendo consigo prendas de vestir $y$ algo de dinero ahorrado para la familia que quedó al cuidado de las casa y de la chacra. Otros emigran definitivamente, llevando consigo a la familia $y$ dejando el pequeño lote de terreno a algún pariente. Algunas veces regresan para las fiestas o no regresan nunca (1969:65)

Díaz creía que algunos comuneros, como los de Moya, habian mantenido cierto grado de equilibrio gracias a un manejo cuidadoso de su limitados recursos. Por lo general, sin embargo, Hambre y Esperanza evita el lenguaje de "adaptación" y "equilibrio" en favor de imágenes de sufrimiento $y$ empobrecimiento.

Díaz compartía la fe de los antropólogos en los méritos de las tradiciones andinas. Pero esto no le impidió que llegara a enfrentarse con la pobreza y la injusticia. La mayor parte de la etnografía andinista se dedicaba a celebrar. Díaz prefería denunciar. El encontró que "la pobreza, la desnutrición, la enfermedad y el analfabetismo, son el común denominador" desde los pueblos jovenes de Huamanga a las palúdicas colonizaciones de la ceja de selva del Apurímac, pasando por las punas ven- 
tosas de los altos de Victor Fajardo (1969:33). Evitando estadísticas extensivas o especializado lenguaje marxista, Díaz optó por retratar las duras condiciones a través de entrevistas informales y agudas observaciones sobre comunidades específicas. En una sección típica, encontramos a Díaz en conversación con José Hinostroza, un migrante de Cangallo al húmedo valle del Apurimac. Díaz nos relata las palabras de Hinostroza para profundizar nuestro entendimiento de la situación en el campo. La conversación fue sosegada. Sin embargo, nos enteramos de la falta de escuelas, los bajos precios para las cosechas, las peleas con el gobiemo y las epidemias devastadoras. Díaz terminaba no con grandes pronunciamientos sino reflexionando sobre las opiniones de Hinostroza mientras caminaba por el resbaloso camino de la casa, comiendo una papaya que la esposa de Hinostroza, una asháninka, le había regalado.

Los campesinos querían el cambio, según Díaz. Su libro nos da una visión de Ayacucho repleta de actividad política. "Las comunidades, las aldeas, villorrios y pueblos luchan por incorporarse y sacudirse de esta estructura colonial, absoleta $e$ inoperante". Escuchamos las quejas de un peón apurimeño sobre su sueldo, las palabras resentidas de un campesino de Cangallo contra funcionarios del gobierno, una invasión de 114 familias campesinas en Huascahura, la historia de otra invasión en La Mar, el rechazo de un grupo de parceleros a una cooperativa administrada por el Estado y la formación de su propia asociación. Para Díaz, esta era una región de un "campesinado desencantado de los poderes públicos", de activa y consciente participación campesina ${ }^{15}$. La "esperanza" de Hambre y Esperanza refería a lo que Díaz consideraba la capacidad de los ayacuchanos para reconstruir su sociedad.

Desilusionado por su propia experiencia a principios de los 60, Díaz consideraba que los tradicionales

15 La cita viene de la contracarátula de Hambre y esperanza. 
modelos asistencialistas de desarrollo no eran una respuesta adecuada a los problemas de Ayacucho. Los ingenieros, agrónomos y administradores de los proyectos de desarollo se convierten en blanco de una crítica dura en Hambre y Esperanza. Para Díaz estos proyectos significaban no un camino hacia el cambio, sino la cara más reciente de la opresión estatal y extranjera. Díaz criticó repetidas veces a la burocracia desarrollista por su paternalismo, insensibilidad por el saber de los campesinos, ineficiencia $y$ corrupción. Como apéndice a Hambre y Esperanza, Díaz incluyó un breve ensayo de un estudiante visitante norteamericano que denunciaba un proyecto de colonización en el Apurímac financiado por A.I.D., a causa de sus gastos inútiles y elitismo. Era esta perspectiva áspera del desarrollo en Hambre y Esperanza, llevada a un extremo cruel, la que llevaría a Sendero Luminoso a hacer de las ONGs y las agencias de desarrollo del estado el blanco de numerosos asesinatos a fines de los 80 y principios de los 90. A principios de 1989, un comunicado senderista decretó la salida de toda ONG extranjera del Perú, porque "dan migajas al pueblo para distraerlo y no se dan cuenta que el camino correcto es el de la guerra popular"16.

Díaz (1969:34) resumía su aversión al desarrollo y su creencia en el potencial revolucionario del campesinado ayacuchano, en un apasionado pasaje con fuertes tonos de Andinismo:

Aquí se desarrolló el hombre del ande dentro de una economía autárquica, hasta que llegó el depredador blanco que persistió durante 300 años $y$, su sucesor, el mestizo moderno: gobernador, cura, diputado, empleado público, y los propagandistas y vendedores de técnica, los ingenieros, que dicen que lograrian el "desarrollo". ¿ "Desarrollo" de

16 La cita viene de Latin American Weekly Report, 5 de octubre 1989, p.12. 


\section{ORIN STARN}

quién?, si ni siquiera atisban a conocer la cultura nativa, ni menos la estructura económica, cómo podrán desarrollarla? Y, sin embargo, este pueblo autóctono se mantiene de pie, con esperanza en el futuro, con fe en sus esfuerzos, y logrará algún dia romper las trabas que impiden su desarrollo.

La rétorica de Díaz reitera que el Andinismo no siempre acompaña una visión del campesinado como conservador. Fue así para los antropólogos con su desinterés en la política. Pero Díaz, al igual que los indigenistas socialistas de los 20 y 30 , conectaba su creencia en la sobrevivencia de tradiciones "autóctonas" con la confianza en las posibilidades de un cambio. Lo andino se volvería la semilla de pureza que floreceria en el nuevo orden social. A diferencia del indigenismo socialista, sin embargo, la ideología de Sendero Luminoso se muestra muy poco dispuesta al Andinismo. En el marxismo ortodoxo del "Pensamiento Gonzalo", se privilegia la importancia de la clase a costa de la etnicidad o identidad cultural. Sendero también se distingue de anteriores movimientos socialistas peruanos por la rigidez atemorizante de su vanguardismo. Es la fría certidumbre de los senderistas respecto de lo infalible de su punto de vista -y su propia misión histórica de liderar a las masas- la que les lleva al asesinato de aquellos que ven como sus opositores. Hambre y Esperanza contenia algunos rasgos de este autoritarismo. Díaz (1969:34-35) dirigía el libro no a los pobres de Ayacucho, sino a los "jóvenes estudiantes $e$ investigadores" de quienes él esperaba reconocieran "la necesidad impostergable y la responsabilidad histórica de estudiar nuestros problemas y tomar una posición honesta en la búsqueda de nuevas situaciones". Aún manteniendo un profundo aprecio por los conocimientos de los campesinos y su iniciativa politica, Díaz también recurría a frases como las "masas miserables" y los "campesinos analfabetos" que daban a entender que la conciencia política campesina no era tan aguda como 


\section{Antropologla andina, “ANdinismo" y Sendero Luminoso}

la de la vanguardia universitaria. El pueblo formaría el corazón de la revolución. Pero tendría que estar organizado en un "estado planificado" (1969:266).

En general, sin embargo, Díaz ofrecía una visión de flexibilidad y colectividad muy diferente a la del dogmatismo del partido que ayudaría a organizar en la década siguiente. La apasionada claridad del joven catedrático aún no se había endurecido en el doctrinarismo. La UNSCH, escribía Díaz (1969:265), debía "ponerse acorde con los ideales del pueblo, para transformar la realidad objetiva del mundo que nos rodea". Pero si no lo lograba, Díaz (1969:24) creía que los pobres de Ayacucho protagonizarían el cambio por cuenta propia, pasando "tarde o temprano.. por encima de ella". Al final de la visión de Díaz (1969:266) estaba un conmovedor pero extrañamente ingenuo sueño de una utopía colectiva. "No olvidemos que este solar nativo, es siempre el mejor para nosotros," escribía en la última linea de Hambre y Esperanza, "hagamos de él un paraíso".

Edward Said (1979:1) habla de cómo el estallido de la sangrienta guerra civil en Beirut en 1974 se estrelló contra la lógica del Orientalismo. Ya no era tan posible representar al Medio Oriente como "un lugar de romance, seres exóticos, recuerdos y paisajes fascinantes, y experiencias extraordinarias". El inicio de la guerra en Ayacucho, a principios de los 80 , llegaría a ser un momento semejante para el Andinismo. Ya no se podía presentar tan fácilmente a la sierra como un lugar de culturas estáticas $e$ identidades rígidamente demarcadas. Alegres afiches de emponchados campesinos andinos al lado de llamas en Macchu Picchu todavía adomaban las paredes de agencias de viajes en Europa, EE.UU., y hasta San Isidro $y$ Miraflores, en Lima. Pero otro tipo de imagen de la 


\section{OrIn StaRn}

sierra también comenzaba a llegar: fotos de fosas comunes, camiones dinamitados, soldados en pasamontañas y familias campesinas velando a sus muertos.

Lejos del paraíso con que soñaba Díaz, la vida en muchas partes de la sierra peruana se ha convertido en una pesadilla. Más de doscientos mil desplazados han huido del terror en el campo para tener una vida sin futuro en los pueblos jóvenes de las ciudades. Los senderistas asesinan autoridades, ingenieros, candidatos políticos y religiosos en nombre de su revolución. Por su parte, las fuerzas gubernamentales han convertido la violación y la tortura en una práctica común. Han desaparecido a más de 3,000 personas desde 1982 y matado a un número aún mayor en masacres y ejecuciones extrajudiciales (Amnesty International 1989:1).

Antonio Díaz Martínez fue una víctima de la guerra. Detenido en Huaraz en 1984, fue uno de los 124 presos detenidos por terrorismo en la cárcel de Lurigancho. Estuvo entre los cerca de 90 prisoneros fusilados después de haberse rendido, cuando la policía retomó Lurigancho tras el motin senderista de junio de 1986. Para evitar autopsias, las fuerzas de seguridad enterraron estos cadáveres de noche en varios cementerios cerca de Lima. El cádaver de Díaz fue descubierto en el cementerio de Imperial en Cañete, al sur de Lima.

Apenas cinco semanas antes del motín, Díaz dio una de las primeras entrevistas de un dirigente senderista a la prensa. José María Salcedo (1986) entró a la cárcel para conversar con Díaz, pasando por el caos del pabellón de los presos comunes llegó hasta el pabellón de los presos por terrorismo, donde los senderistas mantenían una disciplina estricta. Salcedo buscó representar a Díaz como un revolucionario poco convencido. Se concentró en la figura del joven "comisario" senderista que supervisaba la entrevista. Ya se había anunciado que los presos senderistas serian trasladados al nuevo CRAS "Miguel Castro Castro". Díaz anticipaba que las fuerzas de seguridad po- 
Antropologla andina, "Andinismo" y Sendero Luminoso

dian aprovechar la oposición senderista al traslado para justificar una masacre, pero no mostraba temor. "Nuestra moral es superior y tomamos la muerte como un reto", dijo Díaz (citado en Salcedo 1986:64).

Sin embargo, al final la entrevista no confirma el intento de Salcedo de pintar a Díaz como algo menos que un militante convencido de Sendero. Ya era claro que se había vuelto rígido, de línea dura. Sus respuestas eran siempre concisas $e$ inteligentes, pero mostraban el dogmatismo inflexible que ya era aparente en su segundo libro, China, la revolución agraria (1978). Escrito luego de su visita a China en 1974-75 y publicado una década después de Hambre y Esperanza, este libro revelaba la vuelta de Díaz hacia el absurdamente rígido maoismo de la Revolución Cultural. "Desde 1949...la Dictadura del Proleteriado contra la burguesía se había intensificado", escribió Diaz en la primera página del libro, "...y con la Gran Revolución Cultural del Proleteriado la línea roja del Presidente Mao se vuelve más vigente". Desde Lurigancho, Díaz ahora enfatizaba su devoción absoluta al comunismo ("todos somos materia para la transición al comunismo") y citaba al desalmado Guzmán como ejemplo máximo de virtud moral ("la más grande afirmación de la vida sobre la muerte"). Sendero a veces tiene que matar a campesinos, explicó como un buen stalinista-maoísta, porque "el campo no es llano sino dividido en clases".

En cuanto a los antropólogos, sólo un puñado sigue trabajando en el campo de Ayacucho, Apurimac, Huancavelica $y$ Junin $-y$ ningún extranjero entre ellos. A fines de los 70, más de diez grandes proyectos arqueológicos funcionaban en la sierra central y sur; ahora ninguno. Estudiantes extranjeros interesados en los Andes ahora optan mayormente por Bolivia o Ecuador.

Que yo sepa, el único andinista que ha ofrecido reflexiones públicas escritas sobre el por qué los antropólogos no anticipaban a Sendero es Billie Jean Isbell. Su nota introductoria a la segunda edición de To Defend 


\section{ORIN STARN}

Ourselves mezcla una admisión franca de equivocación con una confiada rétorica de continua capacidad. "Mi perspectiva antropológica", escribe, "me cegó a los procesos históricos que ocurrian en el momento...no ubiqué suficentemente a Chuschi en un sistema global en el cual una creciente violencia y el colapso de estados nacionales en el Tercer Mundo están volviéndose cada vez más frecuentes" (Isbell 195:xiii-xiv). Pero Isbell también conserva su misma visión de la continuidad y ensimismamiento andino. No examina las conexiones entre el crecimiento de Sendero y las interconexiones intensificadas en el Perú o el descontento agrario. Al contrario, todavía habla de "una polarización creciente entre las masas quechuahablantes $y$ la cultura nacional", $y$ describe a Sendero como un "pequeño movimiento izquierdista" completamente externo y diferente al campesinado:

Sendero Luminoso ha declarado que está preparado para una lucha de cincuenta años para destruir el Estado existente $e$ instituir un nuevo orden. Los campesinos, en cambio, están concentrándose en preservar sus tierras y su forma de vida (Isbell 1985:xiii).

Por supuesto, este punto de vista es parcialmente cierto. Es esencial que se entienda que Sendero no constituye ninguna sublevación campesina orgánica. Pero Isbell pasa por alto que muchos de los jóvenes en las filas de Sendero son hijos de campesinos. Omite también las corrientes de apoyo a los insurgentes entre los muchos campesinos que quieren el cambio y no sólo defender sus tradiciones. Si Sendero sólo fuera un pequeño grupo de intelectuales izquierdistas violentos, el movimiento hubiera sido destruido hace mucho tiempo. Pero su presencia creció durante los 80 en varias partes de la sierra, e incluso se ha hecho significativo en Lima. Esta insurreción es en parte foránea $y$ en parte autóctona del campo, a la vez terrorista $y$ con cierto respaldo popular. 


\section{Antropologia andina, "Andinismo" y Sendero Luminoso}

Creo que los antropólogos que seguimos en la interpretación de la vida serrana debemos romper definitivamente con el Andinismo. Dos cambios de perspectiva mutuamente relacionados me parecen especialmente imprescindibles. Uno es demantelar la lógica binaria del Andinismo: andino/europeo, indígena/occidental, capitalista/ precapitalista, pagano/cristiano, tradicional/moderno. En vez de presuponer una separación entre lo andino y lo occidental, podríamos comenzar a entender las identidades plurales de la sierra como formas particulares de vivir construidas desde dentro de redes densas y extensivas de poder y representación. Campesinos como los de Chuschi no son, como Isbell (1977:4) aseveraba, "campesinos acercándose a un grado de incorporación nacional". Al contario, han vivido por casi quinientos años bajo un régimen colonial y luego republicano. Carreteras, radios, educación universal, campañas políticas, evangelización, servicio militar obligatorio y la masividad de la migración han apretado los lazos entre el campo andino y los centros urbanos durante este siglo. Reconocer estos densos lazos de ninguna manera significa subestimar las agudas diferencias culturales y económicas en las naciones andinas. Pero sí exige entender estas diferencias no como resultado del aislamiento sino como construídas desde dentro de una historia de conexiones continuas y multidimensionales.

Un segundo cambio clave es dejar de representar las identidades modernas andinas como expresión de la continuidad con un pasado indígena. Lo que Johannes Fabian (1983) denomina el "alocronismo" -la descripción de una tradición cultural contemporánea como si fuera un artefacto de una época histórica anterior- se manifiesta en la presuposición de que las culturas andinas de hoy derivan de los tiempos precoloniales. Por supuesto, sería equivocado ignorar los fuertes vínculos de tanta gente andina con su pasado. Para mencionar sólo el ejemplo más obvio, más de ocho millones de personas todavía hablan quechua, 
si bien salpicado con términos prestados del castellano. Sin embargo, las metáforas de la "continuidad" y el "tradicionalismo" no funcionan muy bien para describir los Andes. De cerca, descubrimos que pinturas taiwanesas colorean los ponchos tejidos a mano. La antigua especialidad culinaria del cuy se prepara con "aji-no-moto". Una de las cantantes más conocidas de la música "tradicional" andina es una nisei, la Princesita de Yungay. Las culturas andinas florecen con vigor aún en la azotada sierra peruana. Pero jamás representan la expresión de rasgos serranos primordiales, siempre el producto de visiones que la gente continuamente redefine en procesos contínuos de innovación y recombinación.

Un activo compromiso para la vida y la paz, creo, debe acompañar la ruptura con el Andinismo. Aunque nuestra contribución sea pequeña, nuestros esfuerzos pueden ser útiles en varios sentidos. Mostrando la vitalidad de la cultura andina podemos ayudar a frenar las visiones que apuntan a afirmar lo deseable de una modernidad homogénea y europeizada, y que se expresan en visiones del Perú que buscan convertirlo en "otra Suiza". Excelentes ejemplos de las potencialidades de este tipo de trabajo son el libro Chayraq (Vásquez y Vargas 1990) sobre el carnaval ayacuchano y la antología del canto quechua, La Sangre de los Cerros, de los hermanos Montoya (1987). También podemos contribuir a difundir entre el público nacional y extranjero un entendimiento de la violencia que vive el Perú, y el peligro tanto del fascismo de Sendero como de la impunidad y la brutalidad de la contrainsurgencia. Aquí ya tenemos como ejemplo a varios importantes trabajos de estudiosos peruanos (Degregori y López Ricci 1990, Degregori 1989, Manrique 1989).

En el fondo, un compromiso político no representa nada de nuevo para los andinistas. Como contribuyentes al desarrollo del Andinismo, hemos ayudado a elaborar un discurso que ha influido no sólo en cómo el resto del mundo percibe los Andes sino también cómo la gente an- 
Antropologla andina, "Andinismo" y Sendero Luminoso

dina se entiende a si misma. Durante este siglo, un sentido idealizado de herencia incaica, armonia con la naturaleza y ética comunal han filtrado por partes de la sierra a través de los textos escolares, la radio, la televisión y el discurso político. Los campesinos, a su vez, pueden tomar elementos de estos conceptos andinistas -muchas veces con partes de los también externamente impuestos discursos de la cristianidad, el nacionalismo y el socialismo- para forjar identidades politicas que respondan a su dura situación contemporánea. En Ayacucho, una cruz de madera, la bandera peruana y unos afiches con lemas antiimperialistas adoman el local de estera y calamina de la Asociación de Familiares de los Desaparecidos (ANFASEP). También hay una poesía reverente de Arguedas al "espiritu andino". Una de las campesinas en la Asociación hace mención a su "herencia comunitaria" y hasta a "nuestros antepasados incaicos" cuando habla de los derechos humanos $y$ de los familiares desaparecidos. En parte, entonces, el Andinismo ha completado el círculo. Lo que comenzó como la imposición de observadores forasteros ahora puede ser retomado en organizaciones populares. Resulta que "nosotros" y "ellos" estamos ligados -además de las conexiones económicas y políticas- por los canales más sútiles de la representación y la auto-imaginación. Queriéndolo o no, entonces, los estudiosos de los Andes estamos siempre vinculados de una manera estrecha y compleja a la gente que estudiamos. Desde luego nos resta la responsabilidad de hacer lo posible para que nuestro involucramiento contribuya a forjar la paz.

Ahora, a principios de 1991, Sendero ha anunciado que su guerra ha pasado de la "defensiva estratégica" a una etapa de "equilibrio estratégico". Las opiniones de los observadores en Lima sobre el futuro de Sendero son variadas. Por un lado, Carlos Iván Degregori (1990) enfatiza los limites de Sendero. En su evocativa metáfora, Sendero sería una "estrella enana" -con un peso en desproporción a su tamaño- que al final es autolimitada en 
su crecimiento por su autoritarismo violento. Por otro lado, Gustavo Gorriti (1990) enfatiza de una manera más pesimista el poder de Sendero. Pinta a los seguidores de Guzmán como una eficiente "máquina de guerra", con la capacidad de triunfar, especialmente si el Estado sigue en su ineficaz contrainsurgencia. Donde todos concuerdan, sin embargo, es en el terriblemente elevado costo humano de estos años de fosas comunes, brutales torturas y niños huérfanos.

En Chuschi, una precaria paz parece haberse establecido a fines de los 80 . Inclusive, los comuneros participaron masivamente en las elecciones presidenciales de abril de 1990. Pero el 14 de marzo de 1991, la tranquilidad fue quebrada. Aparentamente en represalia por su negativa a conformar un Comité de Defensa, la policía en Chuschi detuvo y torturó a cuatro comuneros, tres de ellos autoridades comunales. Esa misma noche, Marcelino Cabana Tucno, Martín Cayllhua Galindo, Manuel Pacotaype Chaupín e Isaías Huamán Vilca fueron llevados al cuartel de Pampa Cangallo por una patrulla militar. EJ ejército niega la detención y los comuneros no han reaparecido. Para los campesinos de Chuschi y tantas otras aldeas serranas, esto sigue siendo lo que Nelson Manrique llama manchay tiempo, tiempo del miedo.

NOTA DEL EDITOR: Este ensayo es una traducción, un poco modificada y actualizada por el autor para su publicación en el Perú, del artículo "Missing the Revolution: Anthropologists and the War in Peru", Cultural Anthropology 6(1), febrero 1991. 


\section{Bibliografia}

Alberti, Giorgio y Enrique Mayer

1974 Reciprocidad andina: ayer y hoy. En Reciprocidad $e$ intercambio en los Andes peruanos. G. Alberti y E. Mayer, eds. Lima: IEP, pp.1337 Amnesty Internacional.

1989 Caught Between Two Fires, Peru Briefing. London: Amnesty Internacional.

Arguedas, José María

1956 Puquio, una cultura en proceso de cambio. Revista del Museo Nacional 26:78-151.

1980 Yawar Fiesta. Lima: Editorial Horizonte. Baker, Paul, y Michael Little, eds.

Baker, Paul y Michael Little, eds.

1976 Man in the Andes: A Multidisciplinary Study of the High-Altitude Quechua. US/IBP Synthesis Series, 1. Stroudsburg: Dowden, Hutchinson, and Ross Inc. 


\section{ORIN STARN}

Bastien, Joseph

1978 Mountain of the Condor: Metaphor and Ritual in an Andean Ayllu. St. Paul, Minn.: West Publishing Company.

Berg, Ronald

1988 Retribution and Resurrection: The Politics of Sendero Luminoso in Peru. Ensayo presentado en la reunión anual de la American Anthropological Association, Phoenix, Arizona.

Bolton, Ralph

1973 Aggression and Hypoglycemia among the Qolla: A Study in Psychobiological Anthropology. Ethnology 12:227-257.

1974

To Kill A Thief: A Kallawaya Sorcery Session in the Lake Titicaca Region of Peru. Anthropos 69:191-215.

Bourque, Susan y Kay Warren

1989

Democracy Without Peace: The Cultural Politics of Terror in Peru. Latin American Research Review 24(I):7-35.

Brush, Stephen

1977 Mountain, Field, and Family: The Economy and Human Ecology of an Andean Valley. Philadelphia: University of Pennsylvania Press.

Buechler, Hans, y Judith-Maria Buechler

1971 The Bolivian Aymara. New York: Holt, Rinehart \& Winston..

Clifford, James

1988 The Predicament of Culture. Cambridge: Harvard University Press. 


\section{Antropologia andina, "Andinismo" y Sendero Luminoso}

Collins, Jane

1989

Unseasonal Migrations: The Effect of Rural Labor Scarcity in Peru. Princeton: Princeton University Press..

Degregori, Carlos Iván

1986 El surgimiento de Sendero Luminoso. IEP: Lima.

Díaz Martínez, Antonio

1969 Ayacucho: Hambre y Esperanza. Ayacucho: Ediciones Waman Puma.

1978 China: La revolución agraria. Lima: Mosca Azul.

Doughty, Paul

1968 Huaylas: An Andean District in Search of Progress. Ithaca, N. Y.: Cornell University Press.

Fabian, Johannes

1983 Time and the Other: How Anthropology Makes Its Object. New York: Columbia University Press.

Flores Ochoa, Jorge

1977 Pastores de Puna. Lima: IEP.

Gonzales Raul

1982 Por los caminos de Sendero. Quehacer 19:3977

Gorriti, Gustavo

1990 Sendero. Historia de la guerra mllenaria en el Perú. Lima: Apoyo. 


\section{ORIN STARN}

Greaves, Thomas

1972

The Andean Rural Proletarian. Anthropological Quarterly 45(2):65-83.

Handelman, Howard

1975

Struggle in the Andes. Austin: University of Texas Press.

Harding, Colin

1988

Antonio Díaz Martínez and the Ideology of Sendero Luminoso. Bulletin of Latin American Research 7(1):65-73.

Isbell, Billie Jean

1977

To Defend Ourselves: Ecology and Ritual in an Andean Village. Austin: University of Texas Press.

1985 Reprinting of To Defend Ourselves. Prospect Heights, Illinois: Waveland Press.

1988

'The Emerging Patterns of Peasants' Responses to Sendero Luminoso. Ensayo presentado en Patterns of Social Change en la Andes Research Conference organizada por NYU and Columbia University LAS Consortium, New York City.

Kawell, Jo Ann

1989 Going to the Source. NACLA 22(6);13-22.

Kirk, Robin

1987 Refugees Rebuild Communities. NACLA 21(56):9-11.

Manrique, Nelson

1989 La década de la violencia. Márgenes 5-6:137152. 


\section{ANTROPOlogia ANDINA, "ANDINISMO" y SENDERo LUMINOSO}

Marcus, George, y Michael Fischer

1986 Anthropology as Cultural Critique: An Experimental Moment in the Human Sciences. Chicago: University of Chicago Press.

Martínez, Hector

1980 Migraciones internas en el Perú. Lima:IEP.

Mauceri, Philip

1989 The Military, Insurgency and Democratic Power:

Peru, 1980-1988. Papers on Latin America.

No. 11. New York: Columbia University, Institute of Latin American and Iberian Studies.

McClintock, Cynthia

1984 Why Peasants Rebel: The Case of Peru's Sendero Luminoso. World Politics 27(1):4884.

Michel-Jones, Francoise

1978 Retour au Dogon: Figure du double et ambivalence. Paris: Le Sycomore.

Montoya, Rodrigo

1980 Capitalismo y No-Capitalismo en el Perú. Lima. Mosca Azul.

Montoya, Rodrigo, Edwin Montoya y Luis Montoya 1987 La sangre de los cerros. CEPES: Lima.

Nash, June 1977

We Eat the Mines and the Mines Eat Us. New York: Columbia University Press.

Nuñez del Prado, Juan Victor

1974 The Supernatural World of the Quechua of Southem Peru As Seen From the Community 


\section{ORIN STARN}

of Qotobamba. En Native South Americans. P. Lyon, ed. Boston: Little Brown, pp. 238250.

Olien, Michael

1973 Latin Americans, Comtemporary Peoples and Their Cultural Traditions. New York: Holt, Rinehart, \& Winston.

Orlove, Benjamin, Michael Foley y Thomas Love eds. 1989 State, Capital and Rural Society: Anthropological Perspectives on Political Economy in the Andes and Mexico. Boulder, Colo.: Westview Press.

Ortner, Sherry

1984 Theory in Anthropology since the Sixties. Comparative Studies in Society and History 26:126-165.

Palmer, David Scott

1986 Rebellion in Rural Peru: The Origins and Evolution of Sendero Luminoso. Comparative Politics 18(2):127-146.

Rivera, Silvio

1980 Oprimidos pero no vencidos. La Paz: CSUTEB.

Rosaldo, Renato

1989 Culture and Truth: The Remaking of Social Analysis. Boston: Beacon.

Roseberry, William

1983 Coffee and Capitalism in the Venezuelan Andes. Austin: University of Texas Press. 


\section{Antropologia andina, "ANdinismo" y Sendero Luminoso}

Said, Edward

1979 Orientalism. New York: Vintage Books.

Salcedo, José María

1986 Con Sendero en Lurigancho. Quehacer 39:6067.

Salomon, Frank

1973 Weavers of Otavalo. En Peoples and Cultures of Native South America. Daniel R. Gross ed. New York: The Natural History Press. pp. 463-485.

1982 Andean Ethnology in the 1970s: A Retrospective. Latin American Research Review 17(2):75-128.

1985 The Historical Development of Andean Ethnology. Mountain Research and Development 5(1):79-98.

Shakespeare, Nicholas

1988 In Pursuit of Guzmán. Granta 23:149-197.

Skar, Harold

1982 The Warm Valley People. New York: Columbia University Press.

Smith, Gavin

1989 Livelihood and Resistance: Peasants and the Politics of Land in Peru. Berkeley: University of California Press.

Stein, Willian

1962 Hualcan: Life in the Highlands of Peru. Ithaca. N.Y.: Comell University Press. 


\section{ORIN STARN}

Stern, Steve, ed.

1987 Resistance, Rebellion, and Consciousness in the Andean Peasant World, 18th-20th Century. Madison: University of Wisconsin Press.

Steward, Julian

1963 Preface. En Handbook of South American Indians, vol. 2. New York: Cooper Square Publications.

Taussig, Michael

1980 The Devil and Commodity Fetishism in South America. Chapel Hill: University of North Carolina Press.

1987

Shamanism, Colonialism, and the Wild Man:

A Study in Terror and Healing. Chicago:

University of Chicago Press.

Thomas, R. Brooke

1976 Energy Flow at High Altitude. En Man in the Andes. P. Baker y M. Little, eds. Stroudsburg: Dowden, Hutchinson, Ross Inc, Pp. 379404.

Trimborn, Hermann

1969 South Central America and the Andean Civilizations. En Pre-Columbian American Religions. W. Krickeberg et al., eds. New York: Holt, Rinehart \& Winston, pp. 83-114.

Valcárcel, Luis

1938 Los estudios peruanos. Revista del Museo Nacional 15:3-12. 
Antropologia ANdina, "ANdinismo" y Sendero Luminoso

1950 Introducción. En Indians of Peru, a book of photographs by Pierre Verger. New York: Pantheon, pp. 1-6.

Wachtel, Nathan

1977 The Vision of the Vanquished. Hassocks: Hanson Press.

Zuidema, R. T. y V. Quispe

1973 A Visit to God. En Peoples and Cultures of Native South America. Daniel R. Gross, ed. Garden City, N.Y.: Natural History Press, pp. 358-373. 